\title{
BMJ Global Health Universal health coverage: the roof has been leaking for far too long
}

\author{
Valéry Ridde (D) , 1,2 Fatoumata Hane ${ }^{3}$
}

To cite: Ridde V, Hane F. Universal health coverage: the roof has been leaking for far too long. BMJ Global Health 2021;6:e008152. doi:10.1136/ bmjgh-2021-008152

Received 30 November 2021 Accepted 1 December 2021

Check for updates

(C) Author(s) (or their employer(s)) 2021. Re-use permitted under CC BY-NC. No commercial re-use. See rights and permissions. Published by BMJ

'Université de Paris, IRD, INSERM, Ceped, IRD, Paris,

France

${ }^{2}$ Institut de Santé et Développement (ISED), Université Cheikh Anta Diop, Dakar, Senegal ${ }^{3}$ Département de sociologie, Université Assane Seck, Ziguinchor, Senegal

Correspondence to Professor Valéry Ridde; valery.ridde@ird.fr
Fix the roof before the rain comes. ${ }^{1}$

$$
\text { —Ghebreyesus TA, WHO Director General. }
$$

When it comes to universal health coverage (UHC), the rain has been doing damage for ages and the roof has been leaking for far too long for some people.

December 12 is World UHC Day-as designated by international experts who have no difficulty in finding quality healthcare in their countries. The accepted definition of UHC is that all people should be able to benefit from quality healthcare, according to their needs, without financial consequences for their families or being subject to trade-offs against other essential expenses.

This technical, even bureaucratic definition is as essential to experts as it is remote from the reality of most vulnerable people in economically high-income countries and the majority of people in low-income and middleincome countries. Abiiro and De Allegri ${ }^{2}$ have shown that the concept of UHC can be perceived differently depending on who is talking about it from a legal, humanitarian, economic, social or public health perspective. The above definition is not univocal. The former Director General of the WHO declared that UHC was the "most powerful concept that public health has to offer'! Its degree of conceptual power and its operational reality remain debatable.

For those who do not see this concept materialising, the slogan put forward this year by UHC 2030 'Leave no one's health behind: invest in health systems for all' may sound like an admission of failure by experts who are obsessed with technical definitions but omit the political nature of UHC choices. In 1980 they promised 'health for all by the year 2000', and recently COVAX promised that $20 \%$ of the African population would be vaccinated against COVID-19. Yet, in Europe, some people are receiving their third dose. There is talk of a fourth before Africa has even reached $6 \%$ vaccinated.
Slogans and objectives are essential to mobilise people, funding and organisations. But when they are repeated over and over again, when progress is so weak, and when preconceived ideas persist, it is necessary to ask questions. We see a kind of permanence in the issues surrounding UHC. Like an antiphon, the idea of forgetting no one and strengthening health systems is constantly repeated. But the funding and actions needed to achieve this ideal are inversely proportional to the rhetoric. In November 2021 in Dakar, UNAIDS (The Joint United Nations Programme on HIV/AIDS) and civil society organisations, together with delegations from 26 countries, reminded us of the need for 'a response that leaves no one behind in the context of COVID-19 and the new pandemics'.

However, this issue of equity and strengthening health systems is too often forgotten in favour of a permanent biomedical and vertical vision of health issues. Like sociologist Pawson's analysis of the COVID-19 pandemic ${ }^{3}$ and anthropologist Geissler's analysis of the public secrets of public health, ${ }^{4}$ we must revisit the 'unspoken' aspects of UHC on this anniversary.

\section{CHALLENGES REPEATED AND FORGOTTEN}

The sidelining of equity in favour of a concentration of objectives and actions on effectiveness is not new. Countries have often engaged in neoliberal reforms of their health systems, as the COVID-19 pandemic has once again revealed. ${ }^{5} \mathrm{~A}$ historical analysis shows that the WHO has an ambiguous discourse on equity. ${ }^{6}$ In Quebec (Canada), it was not until September 2021 that parliamentarians agreed that all children residing or staying in the province, regardless of their place of birth or the migratory status of their parents, should be covered by health insurance schemes. In Burkina Faso, the issue of access to healthcare for the indigent is not of great concern to political leaders, who are constantly calling 
for new studies and new workshops about criteria and targeting processes. ${ }^{7}$ In the Democratic Republic of Congo, the principle of free care and medication for PLHIV (People Living with HIV/AIDS) is not respected despite the announcements. ${ }^{8}$

The solutions drawn from New Public Management (NPM) to reform health systems have also proved ineffective: fee-for-service for physician and activity-based for hospitals, payment by performance, copayments and out-of-pocket expenses, competition between institutions, autonomy, etc. ${ }^{9}$ However, many experts from international organisations and governments, including the WHO, the World Bank and the French Development Agency (AFD), still believe in these solutions. Orthodox economics still has the wind in its sails! $!^{10}$

The privatisation of health financing and the low priority of public financing to support health systems are still very much present. In poorer countries, the health sector is still not a priority. In Rwanda, for example, almost half of health expenditures are financed by official development assistance from rich countries ${ }^{11}$ and policy makers are anchored in the neoliberal ideology of user fees. ${ }^{12}$ In Senegal, the state budget for 2020 allocated only $5 \%$ to the health sector, the same amount as for public order and security.

From the primary healthcare conference in 1978 (Alma Ata Declaration) to the request to reorient health services in 1987 (Ottawa Charter), nothing has really been done to reduce the role of hospitals. Billions continue to be invested in their construction and they have even become the focus of health diplomacy in Africa on the part of China or Turkey, for example. ${ }^{13}$ In Senegal, hospitals absorbed a quarter of health expenditure in 2016. In France, hospital care accounted for almost half of healthcare consumption in 2019 and four times more than care provided by town doctors and midwives. ${ }^{14}$ Outpatient care has been forgotten in the response to the COVID-19 pandemic almost everywhere in the world, confirming that the ambulatory shift that was intended to give it more space still remains wishful thinking. ${ }^{15}$

The systemic vision necessary to meet the needs of populations through care systems is still largely lacking. Like the conference in Dakar, where HIV specialists met to show that they existed, because they felt they had been sidelined during the COVID-19 pandemic. ${ }^{16}$ To each his own pandemic and to each his own disease! None of the guests in the 'rebuilding health systems' session at this conference were recognised experts in health systems strengthening (HSS). At the international level, massive funding has been mobilised for years to fight a few diseases (HIV, malaria and tuberculosis, the fund distribution of which is under debate) to the detriment of others that are less visible, less endowed with advocacy organisations and epistemic communities (eg, road accidents are the leading cause of death in the world among men aged $15-19^{17}$ ).

The global initiative for tools to fight COVID-19 has requested $\$ 18.8$ billion from the international community. By the end of October 2021, almost all the requested funds for vaccines had been secured ( $\$ 12.9$ billion), while the health systems component had only secured $\$ 1.7$ billion of the $\$ 9.5$ billion requested. Over the years, the Global Fund has attempted to address HSS but with little conviction and little expertise. A consultation financed by the AFD confirms that there is a 'gap between the rhetoric or ambitions expressed regarding HSS and the actual scope of its actions' ${ }^{18}$ Instead of taking advantage of the pandemic to open up to health systems, France's national HIV research agency has opened up to other emerging infectious diseases, thus remaining faithful to its historical biomedical and vertical approach.

France's development aid in the field of health during the pandemic in 2020 confirmed this permanence, ${ }^{19}$ as did its support for the creation of the WHO Academy in Lyon and for vaccine manufacturing at the Pasteur Institute in Dakar. During her visit to Dakar for the above-mentioned conference, the French Ambassador for Global Health concentrated her meetings with HIV actors, in a country where HIV affects $0.5 \%$ of the population, ignoring both French and Senegalese implementors and researchers on strengthening health systems. Development anthropologists would surely speak of 'enclicage', ${ }^{20}$ being locked into a network.

\section{KNOWN BUT OFTEN IGNORED CHALLENGES}

In the case of UHC, the role of civil society and communities is less often mentioned, as is that of volunteerism. For example, many people talk about the success of mutual health insurance in Rwanda, forgetting to mention that membership is no longer voluntary but compulsory. ${ }^{21}$ The recurrent failures of community mobilisation for the governance of health centres in Africa, ${ }^{22}$ as well as the challenges of health democracy in Europe and that of community-based health insurance, give rise to increased forms of professionalisation and bureaucratisation whose effectiveness seems clear, as can be seen in Mali and Senegal for district mutual insurance. How can we combine the effectiveness of these professionals with the need for health democracy? ? $^{23}$

While health financing issues are at the heart of the debate on UHC, constantly bringing to the fore the need for public financing, without it being heard (one only has to think, for example, of the colossal sums of money available from the booming mining sector in West Africa ${ }^{24}$ ), the question of quality of care is always much less addressed. Questions of power at the centre of the care relationship and the difficulty of putting a patientcentred health system into practice certainly explain why this challenge is less addressed. ${ }^{22}$

In aid-dependent countries, a topic rarely discussed in public is the influence of partners on the choice of operational solutions. While UHC is a technical issue, it is also a political and values issue. Therefore, the solutions advocated are often embedded in ideologies, when they are not imposed. In Niger, civil servants translate this 
phenomenon with the phrase 'When you're on a given horse, don't look at its teeth'. ${ }^{25}$ It is enough to think of the NPM and its modes of payment by performance pushed by economists at the World Bank and the WHO. ${ }^{9}$

Moreover, conflicts of interest in the advice given are important and rarely mentioned, for example, private consulting firms that propose ready-made solutions for health systems in Africa ${ }^{26}$ but do not forget, in the request they will make to the Global Fund, to add multiple budget lines for their own consultants. ${ }^{27}$ The WHO for its organisational reform ${ }^{28}$ or the French government for the fight against the COVID-19 pandemic and its global health strategy has largely called upon these private companies whose efficiency, neutrality and accountability remain to be seen.

Climate change is still largely forgotten in the context of thinking about UHC, even though scientists have been warning us about it for over six decades. While much research exists on the link between health and climate change (eg, showing the harmful effects of rising temperatures on premature births, the most harmful consequences of which are for the poorest women ${ }^{29}$ ), very little attention is paid to this topic when discussing UHC. This is becoming an urgent matter, both in terms of thinking about the urgent adaptations of healthcare structures and also about how to deal with particular pathologies exacerbated by climate change. A recent report indicates that 'If the health sector were a country, it would be the fifth largest emitter on the planet'. ${ }^{30}$

In this context, we also think of One Health, a concept recently revived by the COVID-19 pandemic, although it is as old as the need to reorient health services. If both issues have been ignored for too long, we need to ask ourselves whether the wave of funding and thinking that One Health will generate will also be an opportunity to put health systems and UHC back into the equation. Animal health, human health and environmental health have lived in parallel for too long.

\section{CONCLUSION}

It is becoming urgent to act to fix the UHC roof because the year 2030 will arrive very quickly! On this yet another anniversary of UHC, many speeches will inevitably be delivered in its favour. However, we are doubly surprised by the historical permanence of, on the one hand, the absence of funding and concrete actions in favour of equity, and on the other hand the narrow vision of global health actors who cannot go beyond their vertical, biomedical and Pasteurian approach. UHC deserves a real policy paradigm shift ${ }^{31}$ in our thinking, our university training, our research approaches and our interventions in the field. Without these shifts, 2030 will arrive, and we will still be making speeches.

Twitter Valéry Ridde @ValeryRidde and Fatoumata Hane @HaneKine

Acknowledgements The authors would like to thank Seye Abimbola for editorial support and Heather Hickey for editing support.
Contributors VR proposed the idea and wrote a draft and then the two authors strengthened and finalised the article.

Funding The authors have not declared a specific grant for this research from any funding agency in the public, commercial or not-for-profit sectors.

Competing interests None declared.

Patient consent for publication Not required.

Ethics approval This study does not involve human participants.

Provenance and peer review Not commissioned; internally peer reviewed.

Data availability statement There are no data in this work.

Open access This is an open access article distributed in accordance with the Creative Commons Attribution Non Commercial (CC BY-NC 4.0) license, which permits others to distribute, remix, adapt, build upon this work non-commercially, and license their derivative works on different terms, provided the original work is properly cited, appropriate credit is given, any changes made indicated, and the use is non-commercial. See: http://creativecommons.org/licenses/by-nc/4.0/.

\section{ORCID iD}

Valéry Ridde http://orcid.org/0000-0001-9299-8266

\section{REFERENCES}

1 Ghebreyesus TA. Fixing the roof before the rain comes, 2021. Available: https://www.who.int/news-room/commentaries/detail/ fixing-the-roof-before-the-rain-comes

2 Abiiro GA, De Allegri M. Universal health coverage from multiple perspectives: a synthesis of conceptual literature and global debates. BMC Int Health Hum Rights 2015;15:17.

3 Pawson R, Manzano A, Wong G. The coronavirus response: known knowns, known unknowns, unknown unknowns. London, 2020.

4 Geissler PW. Public secrets in public health: knowing not to know while making scientific knowledge. Am Ethnol 2013;40:13-34.

5 Sparke M, Williams OD. Neoliberal disease: COVID-19, copathogenesis and global health insecurities. Environ Plan A 2021;0308518X:2110489.

6 Amri MM, Jessiman-Perreault G, Siddiqi A, et al. Scoping review of the world Health organization's underlying equity discourses: apparent ambiguities, inadequacy, and contradictions. Int J Equity Health 2021;20:70.

7 Ridde V, Bonnet E, Kadio K. Demographics in the service of universal health coverage: examples in West Africa. Humanitarian Alternatives 2019;12:33-48.

8 Carillon S, Ridde V. Permanence et invisibilité des paiements directs pour le VIH en République Démocratique du Congo. In: Une couverture sanitaire universelle en 2030? Québec, Canada: Éditions science et bien commun, 2021: 503-30. https:// scienceetbiencommun.pressbooks.pub/cus/

9 Ridde V. The challenges of universal health coverage in sub-Saharan Africa: permanence and failures of New Public Management instruments. In: Une couverture sanitaire universelle en 2030? Québec, Canada: Éditions science et bien commun, 2021: 1-50. https://scienceetbiencommun.pressbooks.pub/cus/

10 Batifoulier P, Boidin B, Domin J-P. La théorie économique l'épreuve de la covid-19: Une lecture d'économie politique de la santé. Regulation.

11 African Region WHO. Status update on the institutionalization of national health accounts in the WHO African region. Brazzaville: WHO Regional Office for Africa, 2021.

12 Chemouni B. The political path to universal health coverage: power, ideas and community-based health insurance in Rwanda. World Dev 2018;106:87-98.

13 Chabrol F, Albert L, Ridde V. 40 years after Alma-Ata, is building new hospitals in low-income and lower-middle-income countries beneficial? BMJ Glob Health 2018;3:e001293.

14 DREES. Les dépenses de santé en 2019. Résultats des comptes de la santé. Paris, 2020. https://drees.solidarites-sante.gouv.fr/sites/ default/files/2021-04/Les\%20dépenses \%20de\%20santé\%20en\%20 $2019 \% 20-\% 20$ Résultats $\% 20$ des $\% 20$ comptes $\% 20$ de $\% 201 a \% 20$ santé\%20-\%20Édition\%202020.pdf

15 Cambon L, Bergeron $\mathrm{H}$, Castel P, et al. When the worldwide response to the COVID-19 pandemic is done without health promotion. Glob Health Promot 2021;28:3-6.

16 UNAIDS. Summit on HIV/AIDS, 2021. Available: https://www.unaids. org/en/resources/presscentre/pressreleaseandstatementarchive/ 2021/november/WCA-summit-closes 
17 Bonnet E, Nikiéma A, Adoléhoume A, et al. Better data for better action: rethinking road injury data in francophone West Africa. BMJ Glob Health 2020;5:e002521. 10.1136/bmjgh-2020-002521.

18 Bekelynck A. Synthèse des résultats de l'étude " Fonds mondial et Renforcement des systèmes de santé en Afrique de l'Ouest et du centre ». Paris: Santé mondiale 2030 et AFD, 2021. http:// santemondiale2030.fr/wp-content/uploads/2020/11/Note-Verte-FMet-RSS-4.pdf

19 Niangaly H, Ridde V, Thuilliez J. Introduction : repenser la santé en Afrique l'aune de la crise sanitaire. Revue internationale des études du développement;247:7-33.

20 Olivier de Sardan J-P. Epistemology, fieldwork, and anthropology. London: Palgrave, 2015.

21 Ridde V, Asomaning Antwi A, Boidin B, et al. Time to abandon amateurism and volunteerism: addressing tensions between the Alma-Ata principle of community participation and the effectiveness of community-based health insurance in Africa. BMJ Glob Health 2018;3:e001056.

22 Abimbola S, Negin J, Jan S, et al. Towards people-centred health systems: a multi-level framework for analysing primary health care governance in low- and middle-income countries. Health Policy Plan 2014;29 Suppl 2:ii29-39.

23 Sheikh K, Abimbola S, World Health Organization,. Learning health systems: pathways to progress: flagship report of the alliance for health policy and systems research. Geneva: World Health Organization, 2021. https://apps.who.int/iris/handle/10665/344891

24 Ridde V, Campbell B, Martel A. Mining revenue and access to health care in Africa: could the revenue drawn from well-managed mining sectors finance exemption from payment for health? Dev Pract 2015;25:909-18.

25 Lavigne Delville P, Aghali A. «A cheval donné, on ne regarde pas les dents " Les mécanismes et les impacts de l'aide vus par des praticiens nigériens. Niamey, Niger: : LASDEL/CRCHUM. Etudes et travaux numéro 2010;83.

26 Topp SM, Schaaf M, Sriram V, et al. Power analysis in health policy and systems research: a guide to research conceptualisation. BMJ Glob Health 2021;6:e007268.

27 Gautier L, Touré L, Ridde V. L'adoption de la réforme du système de santé au Mali : rhétorique et contradictions autour d'un prétendu retour de la santé communautaire. In: Une couverture sanitaire universelle en 2030 ? Québec, Canada: Éditions science et bien commun, 2021: 147-76. https://scienceetbiencommun.pressbooks. pub/cus/

28 Costello $\mathrm{A}$. WHO in its present form is not fit for purpose. BMJ 2021;375:n2644.

29 Chersich MF, Pham MD, Areal A, et al. Associations between high temperatures in pregnancy and risk of preterm birth, low birth weight, and stillbirths: systematic review and meta-analysis. BMJ 2020;371:m3811.

30 Karliner J, Slotterback S, Boyd R. Health care's climate footprint. How the health sector contributes to the global climate crisis and opportunities for action. Health Care Without Harm; Arup 2019.

31 Hall PA. Policy paradigms, social learning, and the state: the case of economic Policymaking in Britain. Comp Polit 1993;25:275-96. 